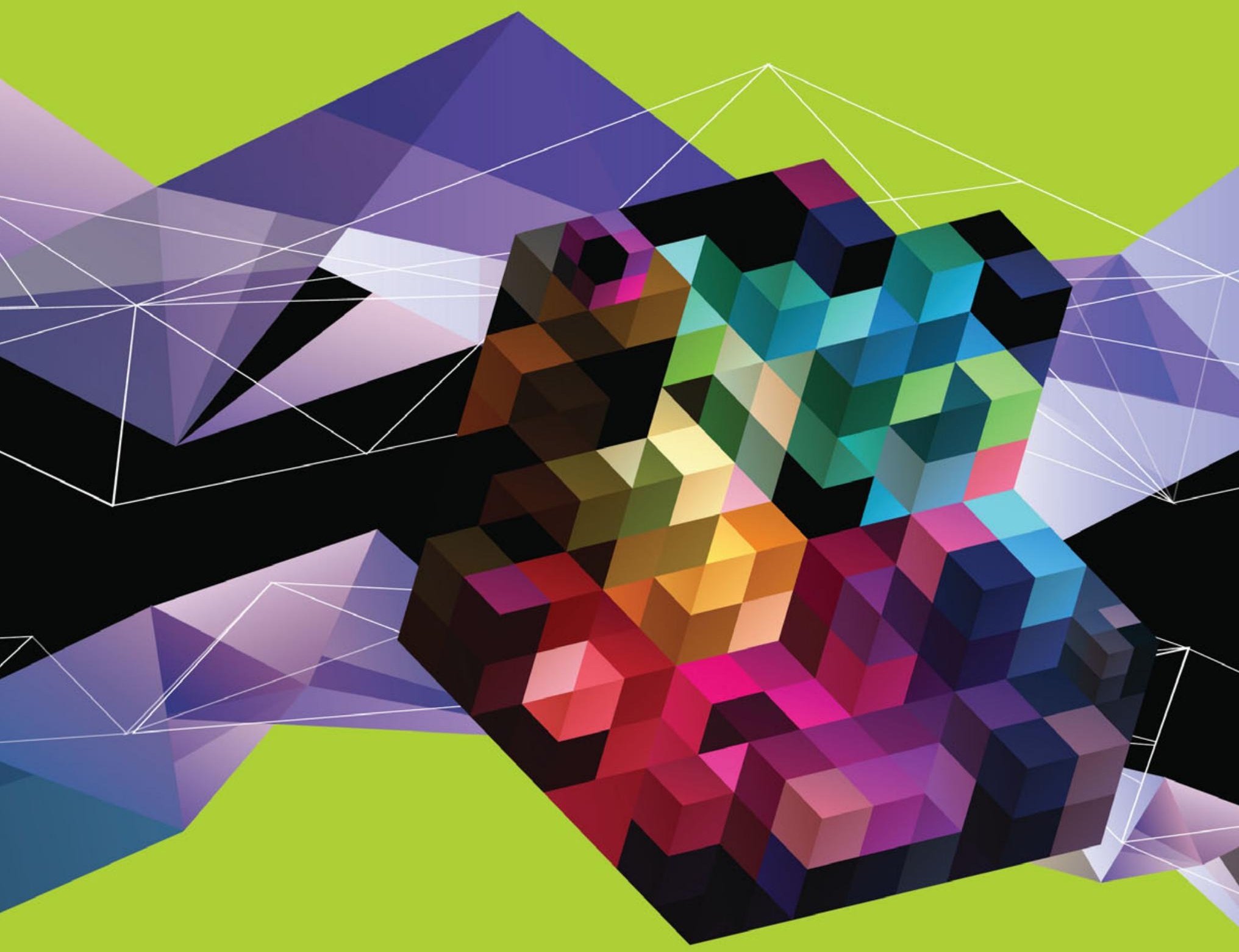

2013 MRS Member Benefits

and Society Activities 
The full suite of MRS publications-MRS Communications, MRS Bulletin, Journal of Materials Research and the MRS Online Proceedings Libraryis now hosted on Cambridge Journals Online (CJO). For both authors and your knowledge readers that means expanded benefits... advanced search capabilities, reference linking, mobile browser accessibility and more!

\section{mRs Communications}

MRS Communications is a full-color, high-impact journal focused on groundbreaking work across the broad spectrum of materials research.

As an MRS member, you'll receive FREE access to MRS Communications on Cambridge Journals Online (CJO). Complimentary access is also available in dynamic pageturning format and mobile applications downloadable from iTunes and the Android Market.

MRS Communications offers a rapid but rigorous peerreview process and time-to-publication with an aggressive production schedule that will bring your article to online publication within a target of 14 days from acceptance.

Leveraging its access to the far-reaching technical expertise of MRS members and leading materials researchers from around the world, the journal boasts an experienced and highly-respected Advisory Board, board of Principal Editors and reviewers.

Major article types for MRS Communications include research letters and prospectives articles.

\section{www.mrs.org/mrc}

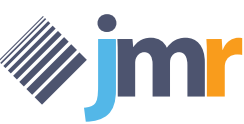

Journal of

MATERIALS RESEARCH

As an MRS member, you may subscribe to Journal of Materials Research (JMR), one of the foremost archival materials research journals in the world, at a very low member rate. All subscription options include full-text articles from the Journal's inception in January 1986 to the current issue.

Look for these JMR benefits and services:

- 24 issues per year

- immediate online publication

- no author page charges/free online color

- advanced search capability

- mobile browser accessibility

- reference linking via CrossRef, Google Scholar and OpenURL

- html or pdf format options for all new JMR content

In addition, five special focus issues will be featured in 2013 : Silicon Carbide-Materials, Processing and Devices in January; Titanium Dioxide Nanomaterials in February; De Novo Carbon Nanomaterials in April; Frontiers in Thin-Film Epitaxy and Nanostructured Materials in July; and Advances in the Synthesis, Characterization and Properties of Bulk Porous Materials in September.

\section{MRSBulletin}

As an MRS member, you can count on your FREE monthly subscription to MRS Bulletin (in print, electronic and dynamic page-turning formats) for the best news and research overviews available today. The technical articles in the Bulletin are among the most highly cited in the field of materials research, consistently ranking in the top $10 \%$ of materials science journals.

Theme topics for 2013 will include:

- Organic single crystals: Addressing the fundamentals of organic electronics

- Nitrogen-vacancy centers: Physics and applications

- Ziegler-Natta catalysis: 50 years after the Nobel Prize

- Paper-based technology

- Interfacial materials with special wettability

- Metal hydrides for clean energy applications

- Ionic liquids for energy/electrochemical applications

- Solid-state surface-enhanced Raman spectroscopy (SERS): Substrates and materials

- Quantum dot light-emitting diodes

- Materials design for quantum computing

- Magnetic nanoparticles

- Functional oxide interfaces

Don't miss Energy Quarterly (EQ)! Bound within MRS Bulletin four times a year, EQ offers interviews and analysis of materials solutions to the world's accelerating need for secure, affordable and environmentally sustainable energy.

\section{www.mrs.org/bulletin}

\section{MRS Online PROCEEDINGS LIBRARY}

The MRS Online Proceedings Library (OPL), FREE to all MRS members, offers unlimited full-text availability to over 100,000 papers from the well-recognized MRS Symposium Proceedings Series-proceedings published from Volume 1 to the present, with more added daily. The collection also includes many proceedings papers that were never published in print format and are available only online.

This massive database is an ideal reference for graduate students, corporate scientists and engineers, and overseas researchers needing access to current information without the lag time of printing and mail delivery.

For our more archivally-minded members, print volumes of the MRS proceedings are available at $15-20 \%$ off list price.

www.mrs.org/opl
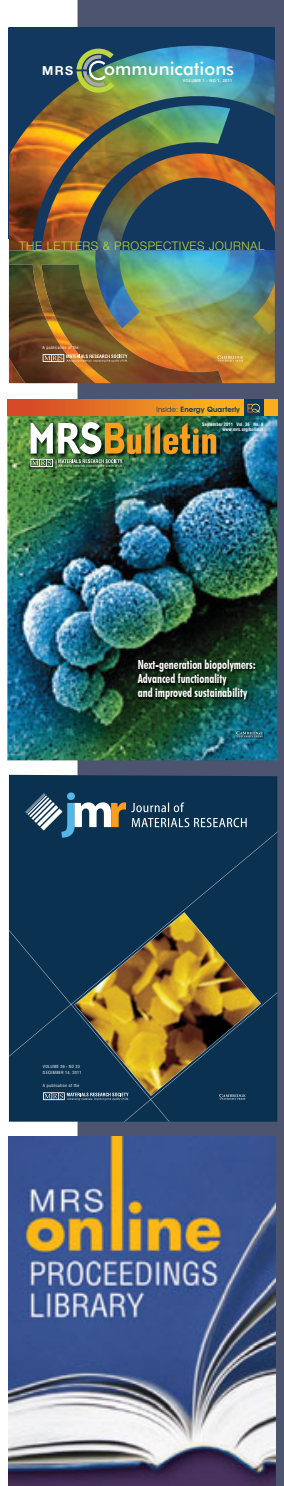



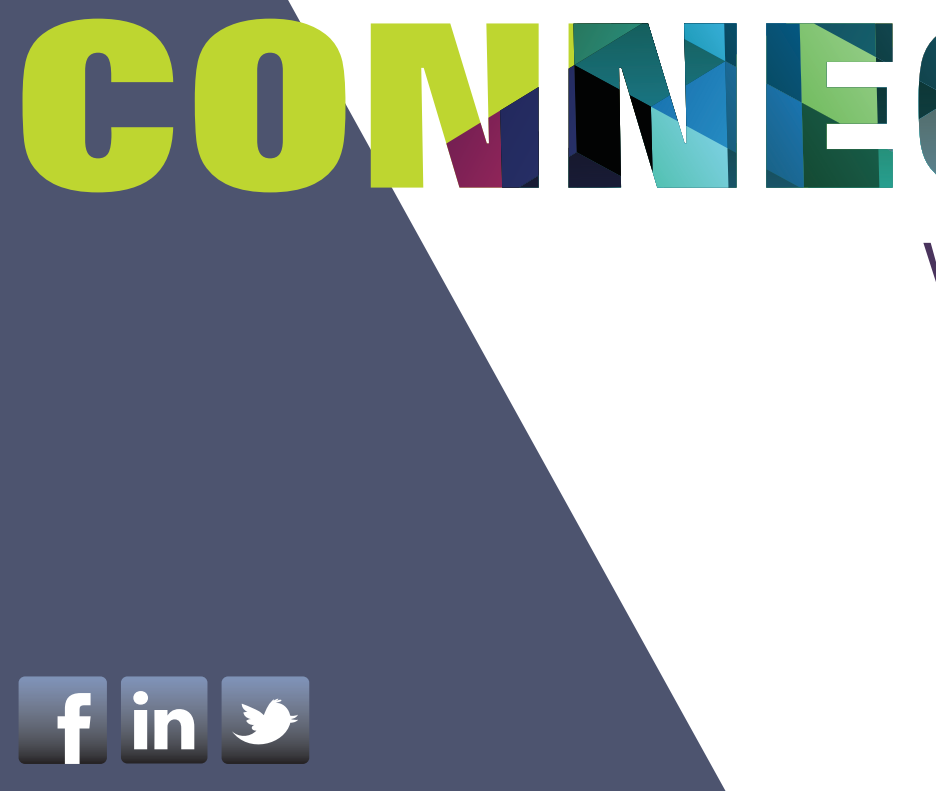

\section{with great minds}

\section{MRS Meetings and Workshops}

The Materials Research Society has always been the "great meetings Society." In 2013, more than 13,000 members from around the world will attend MRS Meetings and Workshops, expanding their professional network of contacts through the exchange of new ideas and information. As an MRS member, you'll enjoy reduced registration fees for these events.

\section{MRS Spring Meeting \& Exhibit}

Moscone West | San Francisco Marriott Marquis |

Westin San Francisco Market Street

April 1-5, 2013 - San Francisco, CA, USA

chang. changing. With new research, awards, publications and conferences announced daily, it's never been more vital to stay upto-date. MRS makes it easy. Connect with fellow materials scientists from around the globe, talk with exhibitors that interest you and share thoughts with MRS staff through our powerful social media channels. Plus, you'll receive exclusive MRS content before anyone else.

Visit www.mrs.org/socialmedia today to view all of our social media channels: Facebook, Linkedln and Twitter.

\section{www.mrs.org/socialmedia}




\section{Additional 2013 Events of Interest to MRS Members}

Plans are also underway for the following events that are organized, coordinated and/or co-sponsored by the Materials Research Society.

www.mrs.org/other-meetings

\section{5th Electronic Materials Conference}

University of Notre Dame

South Bend, Indiana

June 26-28, 2013

\section{International Symposium on Integrated Functionalities}

Dallas, Texas

July 28-31, 2013

\section{0th International Conference on Nitride Semiconductors}

Gaylord National Hotel and Convention Center Washington, DC

August 25-30, 2013

Q1)

The 74th Japan Society of Applied Physics (JSAP) Autumn Meeting

Kyotanabe Campus, Doshisha University Kyoto, Japan

September 16-20, 2013

\section{Photovoltaic Materials} and Manufacturing Issues III

Denver, Colorado

Fall 2013

\section{Member Directory}

The MRS Online Member Directory is a professional networking service available exclusively to our members. Updated regularly, it is a quick and easy way for you to search for colleagues by name, institution or geographical location.

For 2013, MRS has added individualizing features to the Member Directory. By adding pictures, a short bio and links to your social media profiles, your connections to MRS members will be a personalized experience. Log on today to make sure your account is up to date!

\section{www.mrs.org/member-directory}

\section{Career Central}

Opportunities for you to expand your career or your company include the MRS Spring and Fall Meeting career centers, the most efficient forums available for pursuing employment or filling materials research positions. In addition, MRS Bulletin advertises a wide range of materials-related professional openings in industry, academia, government and research worldwide. Listings are also posted on the MRS website each month for convenient online access.

\section{www.mrs.org/career-connections}

\section{University Chapters}

University Chapters are a vital part of MRS, facilitating discussion between students and faculty and promoting student interest in materials science. As a student member, University Chapters give you the platform to network among 72 active Chapters from around the world, compare notes on recent activities and brainstorm with other students on new projects and issues of common concern. Last year, MRS expanded its University Chapters program internationally, allowing student members to connect with different regions globally, maximizing positive impact for materials research worldwide.

www.mrs.org/university-chapters

\section{International Collaborations}

MRS works closely with other materials organizations around the world and is an Adhering Body of IUMRS (International Union of Materials Research Societies). This collaboration facilitates international cooperation among materials research organizations and helps to advance the multidisciplinary nature of the materials research community. Link directly to IUMRS at www.iumrs.org for general information, a list of officers, publications, and upcoming meeting information. 


\section{recognition}

\section{MRS Awards}

The MRS Awards Program acknowledges outstanding contributions to the progress of materials research, honoring those whose work has already impacted the field, as well as those whose work shows great promise for future leadership. www.mrs.org/awards

The MRS Fellow honors members who are notable for their sustained and distinguished contributions to the advancement of materials research worldwide. This designation is highly selective. The maximum number of Fellows that may be appointed in each year is limited to $0.2 \%$ of the current total MRS membership. Nominations are due October 1 of each year.

The Von Hippel Award is the Materials Research Society's highest honor and recognizes those qualities most prized by materials scientists and engineers - brilliance and originality of intellect, combined with vision that transcends the boundaries of conventional scientific disciplines. Nominations are due April 1 of each year.

The David Turnbull Lectureship recognizes the career of a scientist who has made outstanding contributions to understanding materials phenomena and properties through research, writing, and lecturing, as exemplified by the life work of David Turnbull. Nominations are due April 1 of each year.

The MRS Medal recognizes an exceptional recent achievement in materials research which is expected to have a major impact on the progress of any materials-related field. Nominations are due April 1 of each year.

\section{The Innovation in Materials Characterization Award honors an} outstanding advance in materials characterization that notably increases our knowledge of the structure, composition, in situ behavior under outside stimulus, electronic, mechanical, or chemical behavior, or other characterization feature, of materials. Nominations are due October 1 of each year.

The Mid-Career Researcher Award recognizes exceptional achievement in materials research made by mid-career professionals. This annual award is intended to honor an individual who is between the ages of 40 and 52 at the time of nomination and has demonstrated notable leadership in the materials field. Nominations are due October 1 of each year.

The Materials Theory Award recognizes exceptional advances made by materials theory to the fundamental understanding of the structure and behavior of materials. This award is intended to honor both those who have pioneered the development of a new theoretical approach and those who have used existing approaches to provide significant new insight into materials behavior. Nominations are due April 1 of each year.

The MRS Outstanding Young Investigator Award recognizes outstanding, interdisciplinary scientific work in materials research by a young scientist or engineer. The award recipient must also show exceptional promise as a developing leader in the materials area. Nominations are due October 1 of each year.

MRS Graduate Student Awards honor and encourage graduate students whose academic achievements and current materials research display a high order of excellence and distinction. Finalists compete for Gold and Silver Awards at the MRS Spring and Fall Meetings. Applications are due approximately five months preceding each MRS Meeting. which honors the late Arthur Nowick and his lifelong commitment to teaching and mentoring students in materials science, recognizes a Graduate Student Award finalist who shows particular promise as a future teacher and mentor. This award will be presented at each Fall Meeting. 



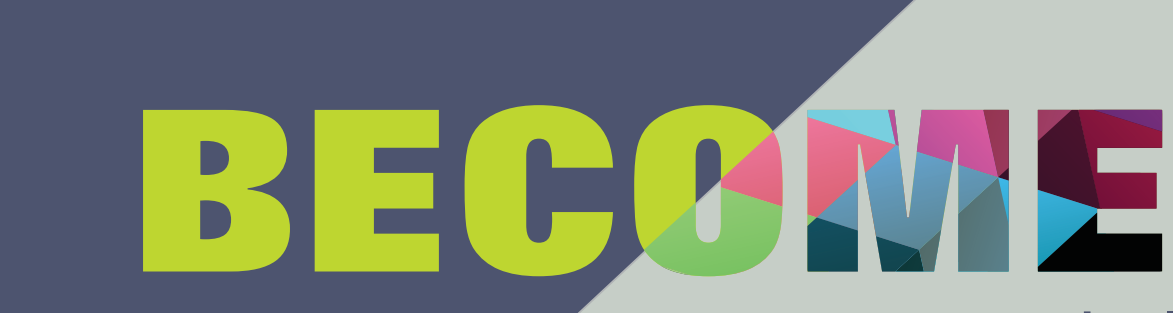

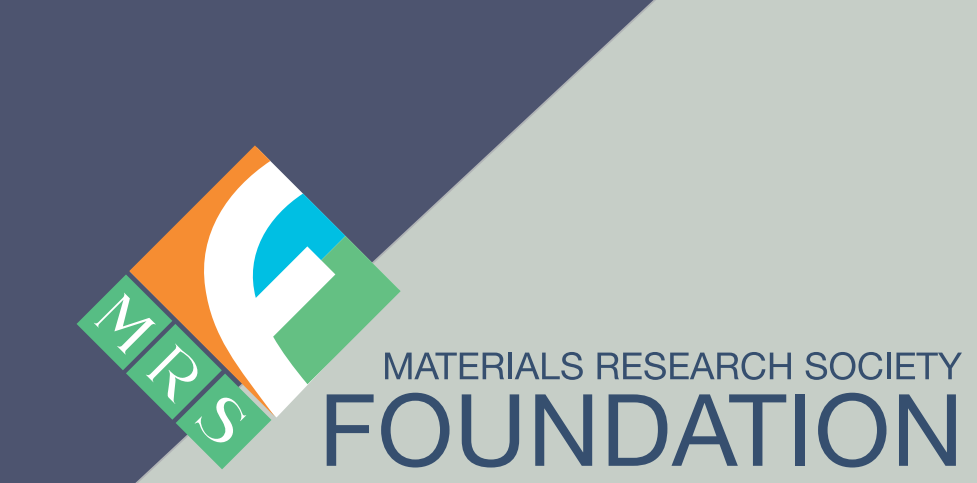

To enhance and expand support for projects that are important, timely and meaningful to the materials community, MRS is proud to announce the Materials Research Society Foundation.

Unique in several ways, the Foundation:

- advances the MRS mission to "promote communication for the advancement of interdisciplinary materials research to improve the quality of life"

- focuses on member engagement and funding to enrich, expand and ensure MRS core programs in education, outreach and peer recognition

- leverages corporate partner, institutional and individual support to invest in projects of importance to the materials community, as defined by the materials community

- benefits a wide range of innovative grassroots, member-driven initiatives-from student chapter proposals, to local or regional education/outreach projects, to those with the potential to impact the materials enterprise worldwide.

To learn how you can help make a difference or to apply for project funding, we invite you to explore the Foundation website.

www.mrs.org/foundation

\section{0} Үิ

MRS recognizes that scientific and engineering communities must strive to become more inclusive, engaging all demographic groups, and that diversity drives innovation, excellence and new discoveries. The MRS Diversity Statement, which was adopted in June 2009, is available online.

\section{www.mrs.org/diversity}

\section{a vital part}

\section{Society Member Volunteers}

The tremendous growth and success of our Society is the result of member input and the energetic efforts of many MRS member volunteers. The MRS committees and task forces offer members an invaluable opportunity to participate in, and influence profoundly, the operation of the Society. A restructuring of our governance has now made such volunteer activities even more effective than they have been in the past. If you have an interest in working on any aspect of MRS activity, contact volunteer@mrs.org.

www.mrs.org/get-involved

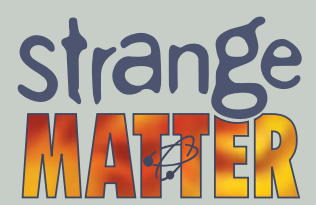

Strange Matter is a traveling interactive exhibition where users enter the fascinating, practical, occasionally bizarre and often beautiful world of materials science through over a dozen handson experiences. Targeting 5th-8th grade students and families, two versions of the exhibition will tour these major science centers throughout North America in 2013:

- London Regional Children's Museum London, Ontario, Canada | September 2012 - January 2013

\section{- Discovery Place}

Charlotte, North Carolina | January - May 2013

- Echo Lake Aquarium \& Science Center Burlington, Vermont | February - May 2013

MRS members will have opportunities to contribute and/or volunteer their services in each of the museum's local communities. For more information, contact Richard Souza at souza@mrs.org. An interactive website (www.strangematterexhibit.com) and a teacher curriculum/activity guide also accompany the exhibit.

The exhibition and its tour are made possible by the National Science Foundation, Dow, Ford Motor Company Fund, Intel Innovation in Education, Rio Tinto Alcan and the $3 M$ Foundation.

www.mrs.org/strangematter 


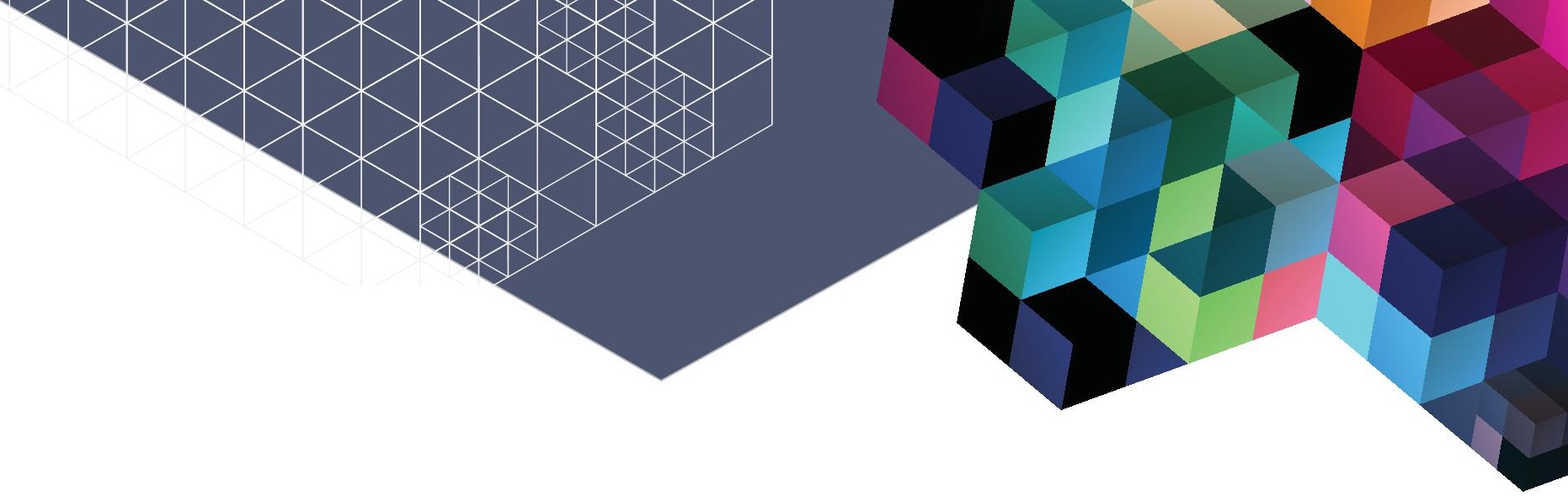

\section{Women in Materials Science and Engineering}

MRS members are encouraged to join the Women in Materials Science \& Engineering (WMS\&E) interest group - an online forum for dialog among women working in, or pursuing education towards, a profession in materials science or engineering. The goal is to share ideas and strategies that may be useful in professional life and to generate ideas for promoting awareness of women's issues to the broad professional community. Subscribe at www.mrs.org/mymrs. Additionally, WMS\&E is also the subject of special breakfasts and professional development workshops at both the MRS Spring and Fall Meetings.

www.mrs.org/mymrs

\section{Science Enthusiasts}

The redesigned Science Enthusiasts web pages invite MRS membership, outreach volunteers and the general public to interact with the stimulating world of Materials Science by becoming Materials Science Enthusiasts and Do Something, Learn Something, Watch Something and Get Involved. The website contains an ever growing collection of resources for the curious learner at any age, as well as for those actively involved in public outreach.

\section{www.mrs.org/science-enthusiasts}

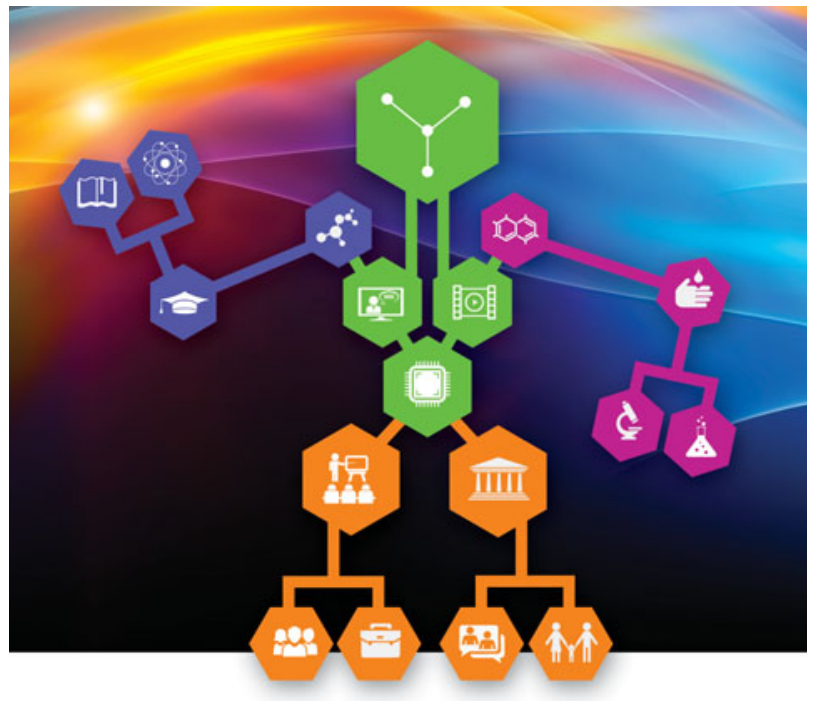

\section{Public Advocacy}

MRS strives to contribute to the development of science and technology policy by responding to, and initiating, opportunities to interact nationally and internationally with government officials as well as public and private organizations. Led by the Government Affairs Committee (GAC), these efforts have been far-reaching, consistent and unbiased, building trust and respect with Washington, DC, both on Capitol Hill and within government agencies. Ultimately, however, the key constituency is you-the MRS member-and GAC is working hard to make your voice heard!

For 2013, MRS will continue to build on its accomplishmentsstrengthening relationships and building new ones through Congressional visits, establishing itself as a scientific resource for policymakers, extending its relationships with leadership in federal agencies, and collaborating in the U.S. and abroad with sister societies and other advocacy organizations when a larger voice for science is required.

To keep abreast of MRS advocacy efforts, register for INTERSECTIONS-Materials Research \& Science Policy, a quarterly electronic newsletter dedicated to strengthening the link between GAC and the MRS members. Log on to www.mrs.org/mymrs to sign up.

www.mrs.org/advocacy

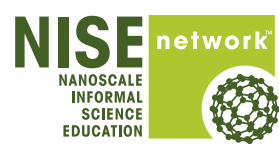

MRS plays a leading role in the Nanoscale Informal Science Education Network (NISE Network)-a program created to engage the public in advances in nanoscale research, to capture the imagination of young people who may subsequently choose careers in nanoscale science and engineering, and to foster new partnerships among research institutions and informal science centers. The NISE Network has selected March 30-April 7 for NanoDays 2013, a national week of community-based educational outreach events to raise public awareness of nanoscale science and engineering and its potential impact on the future. Visit www.nisenet.org to learn more about the NISE Network and NanoDays 2013.

www.mrs.org/NISE 


\section{MRS Membership Rates}

$\square$ I am a new member

$\square$ Please renew my membership

Rates are for 12 months and include complimentary subscription to MRS Bulletin, MRS Communications, and access to the MRS Online Proceedings Library.

Begin Membership:

$\square$ January 1, 2013

$\square$ July 1, 2013

Regular Membership

Student Membership

Retired/Unemployed

$\$ 115.00$

$\$ 30.00 \$$

$\$ 30.00$

Add a subscription to Journal of Materials Research.

Subscription will begin on membership date.

All subscription options to JMR include online access

to full-text articles from January 1986 to the current issue!

$\begin{array}{lll}\text { Member Subscription - online only } & \$ 100.00 & \$ \\ \text { Member Subscription - print and online } & \\ \text { North America } & \$ 248.00 & \$ \\ \text { Rest of World } & \$ 303.00 & \$ \\ \text { Subtotal } & \end{array}$

\section{Materials Research Society Foundation (optional)}

Donations to the Materials Research Society Foundation support the MRS mission, encouraging scientific study and innovationand allow MRS to enhance and extend its awards, honors, education and outreach programs, as well as fund new member-driven grassroots projects.

I am pleased to support the Materials Research Society Foundation.
$\square \$ 10 \quad \square \$ 25 \quad \square \$ 50 \quad \square$ Other

$\square$ I would like my donation to be anonymous

\section{Contribution Options:}

$\square$ Education and Outreach Programs

$\square$ Grassroot, Member-Proposed Projects

$\square$ University Chapter Special Projects

$\square$ Graduate Student Awards

Unless specifically designated above, your contribution

will be used for MRS Education and Outreach Programs.

The Materials Research Society Foundation operates as a program of The Materials Research Society. The official registration and financial information of the Materials Research Society Foundation may be obtained from the Pennsylvania Department of State by calling toll free, within Pennsylvania, 1.800.732.0999. Registration does not imply endorsement.

\section{Payment Information}

\section{$\mapsto$ ENTER PAYMENT TOTAL HERE: $\$$}

$\square$ Check/money order enclosed-payable to Materials Research Society

$\square$ Bill my credit card:

$\square$ MasterCard $\square$ VISA $\square$ American Express

Card No.

Signature

Exp. Date

Mail or Fax

Materials Research Society, 506 Keystone

Drive, Warrendale, PA 15086 USA

Tel 724.779.3003, Fax 724.779.4732

Join/Renew Online www.mrs.org/join

Billing \& Shipping Address

\begin{tabular}{ll}
\hline Name: First & Last \\
\hline Membership ID\# (if renewing) & \\
\hline Institution & Dept./Mail Stop \\
\hline P.O. Box & Street \\
\hline Postal Code & City \\
\hline State/Province & Country \\
\hline $\begin{array}{l}\text { Tel: Country Area/City Local Number } \\
\text { Number }\end{array}$ & Fax: CountryArea/City Local \\
\end{tabular}

E-mail address

Note: The address above will also be used in future MRS Member Directories unless you request an alternate address for the Directory.

\section{Student Applicants}

I am currently enrolled as a full-time student, or I am working full-time on a thesis or dissertation.

Signature

Date

\section{Member Demographics (optional)}

\section{Current Employment Status \\ $\square$ Employed \\ $\square$ Student \\ $\square$ Retired \\ $\square$ Unemployed \\ Highest Level of Education \\ $\square$ Doctorate degree/equivalent \\ $\square$ Master's degree /equivalent \\ $\square$ Bachelor degree/equivalent \\ $\square$ High school graduate/equivalent \\ $\square$ Other}

Year of Highest University Degree Eerned

$\square$

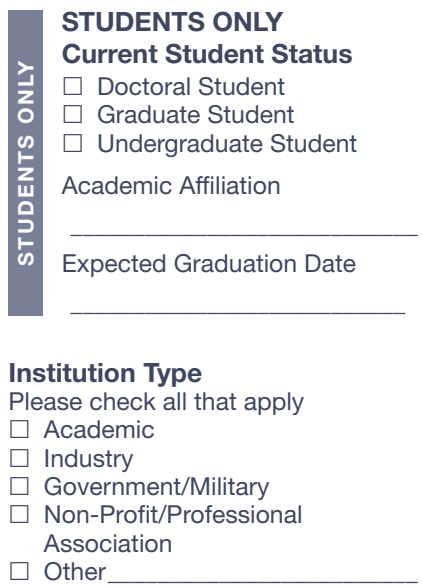

Title/Job Function

$\square$ Executive/Management

$\square$ Scientist/Engineer

$\square$ Professor

$\square$ Department Chair

$\square$ Sales/Marketing

$\square$ Press

$\square$ Student

$\square$ Retired

$\square$ Other

\section{Gender}

$\square$ Male $\square$ Female

Race/Ethnic Origin

$\square$ Asian

$\square$ Black or African Descent

$\square$ Hispanic

$\square$ Native American or Alaskan

$\square$ Native Hawaiian or Pacific Islander

$\square$ White (Caucasian)

$\square$ Other

International Members Only

Do you belong to a group (ethnic, gender, or other) that is considered underrepresented in the fields of

Materials Science and Engineering (including Physics, Chemistry, Engineering) in your country?

$\square$ Yes $\square$ No

If yes, please specify your underrepresented group 